Book Title:

The power of forgiveness

Book Cover:

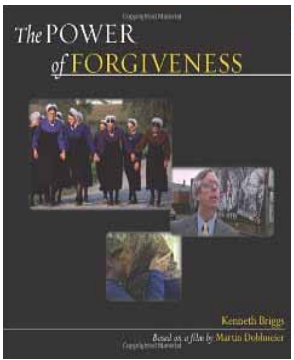

Author:

Kenneth A. Briggs

ISBN:

978-0-8006-6225-7

Publisher:

Fortress, Mineapolis, 2008, pp. 201, cost unknown

Review Title:

To forgive is powerful

Reviewer:

Tiny van der Schaaf ${ }^{1}$

Affiliation:

${ }^{1}$ Department of Practical

Theology, University of

Pretoria, South Africa

email:

tsvanderschaaf@gmail.com

Postal address:

Department of Practical Theology, University of Pretoria, Lynwood Road, Hatfield 0083, South Africa

How to cite this book review: Van der Schaaf, T., 2010,

'To forgive is powerful', HTS Teologiese Studies/ Theological Studies 66(1), Art. \#983, 1 page. DOI: 10.4102/hts.v66i1.983

This review is available at:

http://www.hts.org.za

\section{TO FORGIVE IS POWERFUL}

Dit boek van Briggs is gebaseerd op de film The power of forgiveness van Martin Doblmeier. De interviews, praktijkvoorbeelden en casystudies uit de film zijn door Briggs verwerkt in een boek met achtergrondinformatie. In zijn inleiding beweert Briggs dat wij door bijbelverhalen bewust worden van het feit dat wij mensen vergeving nodig hebben en dat we moeten overwegen om aan anderen vergeving te schenken (bl. 4). Vergeving maakt complexe patronen tussen mensen zichtbaar. Vergeving is een macht waarvan de volle omvang niet kan worden achterhaald (bl. 6). Briggs neemt vanuit verschillende gezichtspunten het begrip vergeving onder de loep. Hij begint met een zoektocht naar de religieuze wortels (bl. 9-32). In het tweede hoofdstuk gaat hij in op de invloed van vergeving op het psychische welzijn (bl. 33-56). Vervolgens wijdt Briggs een hoofdstuk aan de grenzen van vergeving (bl. 57-76). In het vierde hoofdstuk gaat het over de kracht van vergeving (bl. 77-98). Hoofdstuk vijf behandelt de zelfvergeving (bl. 99-119), waarna in hoofdstuk zes de verhouding tussen vergeving en recht aan de orde komt (bl. 120-140). In hoofdstuk zeven gaan Briggs dieper in op de situatie wederkerigheid in gevallen waar beide partijen schuld hebben (bl. 141-160). Het laatste hoofdstuk verkent de onontbeerlijkheid van vergeving wanneer het gaat om het overleven van een natie (bl. 161-180). Briggs sluit het boek af met een epiloog over de reis richting vergeving (bl. 181-197).

Zoals uit het voorgaande gebleken is, wordt het begrip vergeving vanuit vele gezichtspunten verder bekeken. Waarschijnlijk is dit de oorzaak dat de analyses wat oppervlakkig blijven. Een voorbeeld hiervan is de vergelijking van vergeving binnen de grote religies. Briggs beweert dat zowel het Jodendom als het Christendom geen middelaar hebben (bl. 18). Een paar pagina's daarvoor schrijft hij echter dat het Christus is vergeving mogelijk maakt (bl. 16). Een ander voorbeeld van deze oppervlakkigheid wordt zichtbaar in het zesde hoofdstuk, waar de auteur zelf aangeeft dat voor slachtoffers van verkrachting en moord juridische straf de enige mogelijkheid is. Briggs gaat niet in op hoe vergeving voor deze mensen dan wel kan functioneren.

Samengevat; dit boek belicht het begrip vergeving van vele kanten, hetgeen waardevol is. Dit gaat echter wel ten koste van de diepgang. (c) 2010. The Authors. Licensee: OpenJournals Publishing. This work is licensed under the Creative Commons Attribution License. 